\title{
О РЕЗУЛЬТАТАХ СЕЛЕКЦИИ ПШЕНИЦЫ СПЕЛЬТА (Triticum spelta L.) НА ПРОДУКТИВНОСТЬ И КАЧЕСТВО ЗЕРНА
}

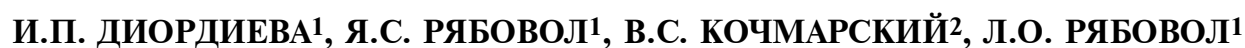

Спельта (Triticum spelta L.) - древний вид пшеницы, спрос на который в настоящее время растет. Несмотря на ряд ценных признаков (высокое содержание белка, клейковины и аминокислот в зерне, высокий адаптивный потенциал, наличие мощного стебля и высокая устойчивость к полеганию), она существенно уступает пшенице мягкой T. aestivum L. по урожайности. Однако от скрещиваний пшеницы спельта с пшеницей мягкой можно получать новые перспективные генотипы с улучшенными количественными показателями за счет интрогрессии в геном T. spelta генетического материала $T$. aestivum. В настоящей работе в результате гибридизации пшеницы мягкой со спельтой мы получили ряд новых форм, которые различаются между собой по морфобиологическим и хозяйственно ценным признакам. Целью наших исследований было получение исходных форм пшеницы спельта с высоким качеством зерна на основе гибридизации Triticum aestivum и $T$. spelta и их введение в селекционную схему создания высокопродуктивных сортов культуры. Образцы пшеницы спельта получали методом отдаленной гибридизации с помощью многократных индивидуальных отборов. В качестве исходного материала привлекали образцы спельта местной селекции с предгорных районов Карпат и районированные сорта озимой мягкой пшеницы Фаворитка, Харус, Панна, Ермак, Подолянка, Крыжинка, Фарандоль, Копиловчанка, Краснодарская 99 и др. Полученные от скрещивания гибриды F1 самоопыляли или повторно скрещивали с родительскими формами. Гибридное потомство F2-5 анализировали по морфобиологическим и хозяйственно ценным показателям (высота растений, форма куста, наличие воскового налета на растениях и опушения на стебле и колосе, длина, цвет и остистость колоса, число колосков в колосе, плотность колоса, обмолачиваемость зерна, форма и цвет зерновки, масса зерна с главного колоса, число продуктивных стеблей на растении, масса 1000 зерен, содержание в зерне белка и клейковины, стекловидность, урожайность). В пятом поколении (F5), когда расщепление уже не наблюдалось, с учетом продуктивности и качества зерна предыдущих лет отобрали 18 лучших образцов пшеницы спельта. Их тестирование проводили в 20122018 годах (F5-11) на опытном поле Уманского национального университета садоводства (правобережная лесостепь Украины, Черкасская обл.). Содержание клейковины и белка в зерне оценивали методом инфракрасной спектроскопии с использованием прибора Infratec ${ }^{\mathrm{TM}}$ Nova («FOSS Analytical», Швеция). Биометрические показатели (высоту растений, длину колоса, число зерен в колосе, массу зерна с главного колоса) определяли на 50 растениях, отобранных с каждого участка в 2 несмежных повторениях. Проводили обмолот и определяли урожайность образцов. В результате скрещиваний была создана коллекция исходных форм спельты, включающая более 200 образцов. Полученные формы разделили на четыре группы по высоте растений: полукарлики, низкорослые, среднерослые и высокорослые. В каждой группе отбирали лучшие образцы, которые проанализировали по качеству зерна, урожайности и ее структуре. Была доказана возможность селекционного улучшения спельты на основе межвидовой гибридизации с пшеницей мягкой. По урожайности восемь образцов существенно превосходили стандарт. При этом селекционные образцы 76, 155, 1695 и 1725 характеризировались улучшенной обмолачиваемостью зерна (80$90 \%$ ), а образцы 76 и 1817 обладали также высокими показателями качества зерна, в частности содержание белка в них составляло соответственно 25,2 и 22,0 \%, клейковины - 52,1 и 44,7 \%. По количеству белка и клейковины в зерне лучшими были образцы 40 и 13 (содержание белка соответственно 30,1 и 27,2 \%, клейковины - 63,2 и 56,5 \%). Образец 124 выделялся низкорослостью (высота растений 92 см), высокими показателями качества зерна (масса 1000 зерен 53,8 г, содержание белка в зерне - 17,9\%, клейковины I группы качества - 37,4 \%), образец 155 - высокой продуктивностью (5,36 т/га) и улучшенной обмолачиваемостью (92 \%). При гибридизации спельты и пшеницы мягкой был создан сорт пшеницы спельта озимой Европа, который занесен в Державний реєстр сортів рослин, придатних для поширення в Україні (с 2015 года).

Ключевые слова: пшеница спельта, пшеница мягкая, гибридизация, урожайность, обмолачиваемость, содержание белка, содержание клейковины.

Спельта (Triticum spelta L.) - один из самых древних возделываемых видов пшеницы, который был известен еще в VII-VIII тысячелетии до н.э. Центр происхождения спельты находится в Юго-Восточной Азии, откуда она распространилась в Северную и Центральную Европу. Азиатские подвиды спельты, скорее всего, получены в результате спонтанной 
гибридизации видов T. turgidum ssp. dicoccon и Aegilops tauschii ssp. strangulata, а позже от нее произошли голозерные гексаплоидные виды, в том числе $T$. aestivum L. По геномному составу и структуре хромосом некоторых геномов спельта идентична пшенице мягкой $(1,2)$.

Спельту выращивали в древние времена, но постепенно она исчезла из посевов в связи с невысокой урожайностью. Сейчас спрос на спельту растет, что объясняется высоким содержанием белка в зерне и наличием ряда питательных веществ и аминокислот, которые не могут быть получены с продуктами животного происхождения (3-6). По содержанию белка в зерне спельта превосходит вид T. aestivum на 8-10\%, T. sphaerococum Persiv. - на 3-8 \%, T. petropavlovskyi Udacz. et Migusch - на 2-6\% (7-10). По количеству триптофана она превосходит пшеницу мягкую на 10-15\%, твердую - на 15-20\%, а также содержит на 16-20 \% больше клейковины, чем пшеница мягкая. Кроме того, в зерне спельты содержится меньшее количество глютена, чем у пшеницы мягкой, ячменя, овса, что позволяет использовать спельту в диетическом питании $(11,12)$.

Сейчас вниманию производителей представлено небольшое число сортов спельты, а ее генетическое разнообразие ограничивается в основном местными формами народной селекции. В связи с этим спельта не может конкурировать с пшеницей мягкой $(3,13)$. Актуальная задача селекции спельты - повышение продуктивности при сохранении высокого содержания белка и клейковины в зерне $(14,15)$. Скрещивая T. spelta с T. aestivum, можно получить новые гибридные формы с улучшенными качественными показателями.

Ряд ученых, занимающихся селекционным улучшением спельты посредством ее скрещивания с пшеницей мягкой, указывают на положительный эффект от гибридизации, в частности сушественное расширение генетического разнообразия и получение новых трансгрессивных форм (14, 16-18). Однако, по мнению А.И. Рыбалки (19), такие скрещивания нежелательны, поскольку приводят к ухудшению качества зерна у спельты, а у мягкой пшеницы - наследованию признака трудной обмолачиваемости зерна и ломкости колоса.

Основные задачи селекции пшеницы спельта в Украине - повышение продуктивности, снижение высоты растений, улучшение эффективности обмолота зерна. Масштабные исследования по этим направлениям развернуты в Институте растениеводства им. В.Я. Юрьева НААН (г. Харьков), Мироновском институте пшеницы им. В.Н. Ремесла НААН (п. Центральный, Киевская обл.), Всеукраинском научном институте селекции (ВНИС) (г. Киев) и Уманском национальном университете садоводства (УНУС) (г. Умань) (20-22). Совместными усилиями ученых УНУС и ВНИС созданы первые два сорта пшеницы спельта озимой - Заря Украины и Европа, которые включены в Державний реєстр сортів рослин, придатних для поширення в Україні (23). Однако спельта по-прежнему остается малораспространенной культурой, которая требует селекционного улучшения.

В настоящей работе в результате гибридизации пшеницы мягкой со спельтой мы получили ряд новых форм, которые различаются между собой по морфобиологическим и хозяйственно ценным признакам.

Целью наших исследований было создание исходных форм пшеницы спельта с высоким качеством зерна на основе гибридизации Triticum aestivum и T. spelta и их введение в селекционную схему создания высокопродуктивных сортов культуры.

Методика. Образцы пшеницы спельта получали методом отдален- 
ной гибридизации с помощью многократных индивидуальных отборов. Создание коллекции было начато в 2006 году под руководством Ф.Н. Пария. В качестве исходного материала привлекали образцы спельта местной селекции из предгорных районов Карпат и районированные сорта озимой мягкой пшеницы Фаворитка, Харус, Панна, Ермак, Подолянка, Крыжинка, Фарандоль, Копиловчанка, Краснодарская 99 и др. (всего около 60 сортов). Гибридизацию проводили посредством ручной кастрации цветков материнской формы и их принудительного опыления пыльцой отцовского родителя. Сбор и учеты продуктивности осуществляли в фазу полной спелости.

Гибридное потомство F2-5 анализировали по следующим морфобиологическим и хозяйственно ценным показателям: высота растений, форма куста, наличие воскового налета на растениях и опушения на стебле и колосе, длина, цвет и остистость колоса, число колосков в колосе, плотность колоса, обмолачиваемость зерна, форма и цвет зерновки, масса зерна с главного колоса, число продуктивных стеблей на растении, масса 1000 зерен, содержание в зерне белка и клейковины, стекловидность, урожайность. В пятом поколении $\left(\mathrm{F}_{5}\right)$, когда расщепление уже не наблюдали, с учетом продуктивности и качества зерна предыдущих лет отобрали 18 лучших образцов пшеницы спельта, которые стали объектом исследований. Их тестирование проводили в течение 2012-2018 годов (F5-11) на опытном поле Уманского национального университета садоводства (правобережная лесостепь Украины, Черкасская обл.).

Содержание клейковины и белка в зерне определяли методом инфракрасной спектроскопии с использованием прибора Infratec ${ }^{\text {тм Nova }}$ («FOSS Analytical», Швеция). Высоту растений измеряли в полевых условиях перед сбором урожая по методике Государственной научно-технической экспертизы сортов (24). Образцы группировали по высоте растений согласно методике В.Ф. Дорофеева с соавт. (25). В опытах использовали систематический метод размещения участков с учетной площадью $10 \mathrm{~m}^{2}$. Номера располагали блоками с густотой растений 400 тыс. шт/га. Повторность опыта 5-кратная. Биометрические показатели (высоту растений, длину колоса, число зерен в колосе, массу зерна с главного колоса) определяли на 50 растениях, отобранных с каждого участка в 2 несмежных повторениях. Проводили обмолот и определяли урожайность образцов. Обмолачиваемость зерна оценивали как отношение количества обмолоченного зерна к общему количеству зерна с участка, выраженное в процентах.

Экспериментальные данные обрабатывали статистически с помощью программы Microsoft Excel 2010. При определении средних $(M)$ вычисляли их стандартные ошибки $( \pm \mathrm{SEM})$ и относительную ошибку выборки (ошибка опыта, $\mathrm{S} x, \%)$. Наименьшую существенную разность $\left(\mathrm{HCP}_{0,99}\right.$ для содержания клейковины и белка в зерне, НСР 0,95 - для остальных показателей) и коэффициент вариации ( $C v, \%)$ рассчитывали по методике Э.Р. Эрмантраута и В.П. Гудзя (26).

Результаты. Исходная форма пшеницы спельта была высокорослой (более 120 см), имела длинный (20 см), неплотный, узкий, ломкий, пленчатый, безостый колос белого цвета без воскового налета. Колос при дозревании ломался на отдельные членики и характеризировался трудным обмолотом зерна в связи с наличием грубых, плотных колосковых пленок. У исходной формы продуктивность составляла 4,15 т/га, содержание белка - $25 \%$, клейковины - 50-52 \%. Исходные сорта пшеницы мягкой относились к полукарликовой (Копиловчанка, Панна, Ермак, Харус) или низкорослой (Фаворитка, Подолянка, Краснодарская 99, Крыжинка, Фа- 
рандоль) группе. Все сорта голозерные, с оптимальной обмолачиваемостью, различающиеся между собой по апробационным (восковой налет, опушение растений и колоса, цвет растения, колоса и зерна, форма, плотность и длина колоса, размер и форма колосковой чешуи, форма куста, остистость-безостость, форма и крупность зерна) и хозяйственно ценным (урожайность, содержание белка и клейковины) признакам.

Полученные от скрещивания гибриды F1 самоопыляли или повторно скрещивали с родительскими формами. Значительное генетическое разнообразие, которое было вовлечено в гибридизацию, обеспечило широкий формообразовательный процесс в поколениях гибридов. При этом особое значение уделяли детальной проработке материала на начальных этапах селекционного процесса, поскольку только рекомбинационная изменчивость в поколениях F2-4 обеспечивает получение новых трансгрессивных по хозяйственно ценным признакам форм растений (27).

С помощью индивидуально-семейного отбора среди потомков были выделены образцы пшеницы спельта, которые характеризовались существенным разнообразием по морфобиологическим признакам. В состав рабочей коллекции вошли раннеспелые низкорослые формы с высокой зимо- и морозостойкостью и другими ценными признаками. Некоторые формы превосходили исходные сорта по урожайности, содержанию белка и клейковины в зерне, продуктивности колоса (табл. 1).

Пшеница спельта отличается высокорослостью $(28,29)$, поэтому актуально снижение высоты стеблестоя при сохранении высокого содержания белка и клейковины. Рабочая коллекция включала формы, значительно различающиеся по высоте растений. Размах изменчивости по этому признаку составлял 52-129 см.

Согласно данным ряда ученых, гибриды, полученные при скрещивании различных видов пшеницы, по высоте растений занимают промежуточное положение между исходными формами $(15,30,31)$. Однако в научной литературе описаны факты доминирования и сверхдоминирования высокорослого родителя $(14,32,33)$. В потомстве также фиксируют селекционную (аддитивное взаимодействие генов) и гибридную (комплементарное взаимодействие генов) карликовость (34).

Сравнительное изучение более 200 коллекционных образцов спельты и исходных форм указывает на различный характер наследования высоты растений: от типичного промежуточного до гетерозиса и доминантной карликовости. Созданные образцы были разделены на высокорослые (более 120 см), среднерослые (105-119 см), низкорослые (85-104 см), полукарликовые (60-84 см) и карликовые (менее 60 см) согласно классификации В.Ф. Дорофеева с соавт. (25). Наиболее многочисленными и продуктивными оказались низкорослая и среднерослая группы.

В литературе представлено мало данных о генетическом контроле высоты растений у T. spelta. В поколениях F5 от скрещиваний высокорослых форм были получены высокорослые потомки, что дает основания предполагать наличие у спельты высокорослости (1). При гибридизации спельты с сортами пшеницы мягкой, несущими доминантные или рецессивные гены карликовости, наблюдают различные типы взаимодействия генов (комплементарное, эпистатическое, полимерное) и формирование потомков с широким размахом изменчивости по высоте растений.

Пшеница спельта имеет длинный неплотный колос, что приводит к его низкой озерненности. При селекции важно повысить плотность ко- 
лоса, что, в свою очередь, позволит улучшить продуктивность.

1. Структура урожая образцов пшеницы спельта (F5-11), созданных посредством гибридизации Triticum aestivum L. $\times$ Triticum spelta L. (M \pm SEM, Украина, Черкасская обл., 2012-2018 годы)

\begin{tabular}{l|l}
\hline Генотип & $\begin{array}{l}\text { Материнска } \\
\text { форма }\end{array}$ \\
\hline Средний показатель \\
по группе \\
$1786 \quad$ Фаворитка \\
$1817 \quad$ Харус \\
$\mathrm{HCP}_{0,95}$ \\
Cv, \% \\
$\mathrm{SX}_{\mathrm{X}} \%$
\end{tabular}

Средний показатель

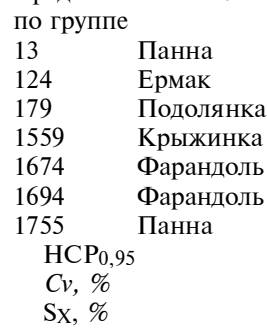

Средний показатель

\begin{tabular}{|c|c|}
\hline по гр & \\
\hline 40 & Панна \\
\hline 76 & Крыжинка \\
\hline 155 & Панна \\
\hline 1721 & Панна \\
\hline 1725 & Копиловчанка \\
\hline $\mathrm{HC}$ & \\
\hline $\begin{array}{l}C v, \\
S x\end{array}$ & \\
\hline
\end{tabular}

Средний показатель

$\begin{array}{ll}\text { по группе } & \\ 86 & \text { Панна } \\ 1691 & \text { Краснодарская } 9 \\ 1695 & \text { Фарандоль } \\ 1730 & \text { Фаворитка } \\ \text { HCP } 0,95 & \\ C v, \% & \\ \text { Sx \% } & \end{array}$

$\begin{array}{cc}2,04 \pm 0,051 & 15,1 \pm 0,20 \\ 2,02 \pm 0,063 & 15,5 \pm 0,22 \\ 2,56 \pm 0,090 & 18,0 \pm 0,28 \\ 0,07 & 0,6 \\ 9,28 & 10,8 \\ 3,41 & 3,9 \\ \text { Н и з к о р о с лы е }(85-104\end{array}$

Н и з к ор ослы е (85-104 см)

$\begin{array}{ccc}1,52 \pm 0,081 & 14,2 \pm 0,15 & 45 \pm 0,3 \\ 1,41 \pm 0,062 & 13,6 \pm 0,18 & 42 \pm 0,3 \\ 1,88 \pm 0,089 & 12,9 \pm 0,15 & 45 \pm 0,3 \\ 1,47 \pm 0,050 & 13,1 \pm 0,16 & 46 \pm 0,3 \\ 2,40 \pm 0,122 & 18,0 \pm 0,24 & 48 \pm 0,4 \\ 2,02 \pm 0,113 & 14,4 \pm 0,20 & 45 \pm 0,3 \\ 1,74 \pm 0,102 & 18,3 \pm 0,23 & 44 \pm 0,3 \\ 2,33 \pm 0,131 & 17,1 \pm 0,22 & 46 \pm 0,4 \\ 0,06 & 0,5 & 2 \\ 13,45 & 14,3 & 3 \\ 3,94 & 3,5 & 4,4 \\ \text { С ре д н е ос лы е }(105-119 \text { см) }\end{array}$

$1,54 \pm 0,062$
$1,24 \pm 0,028$
$1,81 \pm 0,080$
$1,85 \pm 0,071$
$1,58 \pm 0,049$
$1,53 \pm 0,052$
0,06
6,34
3,8
В ы с о

$1,75 \pm 0,060$
$1,89 \pm 0,091$
$2,05 \pm 0,132$
$2,70 \pm 0,149$
$1,76 \pm 0,064$
0,06
12,25
3,4
3,4

$\begin{array}{cc}14,8 \pm 0,20 & 44 \pm 0,3 \\ 14,5 \pm 0,21 & 39 \pm 0,3 \\ 15,2 \pm 0,24 & 42 \pm 0,3 \\ 16,5 \pm 0,28 & 45 \pm 0,3 \\ 17,4 \pm 0,31 & 42 \pm 0,3 \\ 17,3 \pm 0,29 & 45 \pm 0,4 \\ 0,5 & 2 \\ 12,6 & 2 \\ 3,6 & 4,5 \\ \text { с л ы е (> } 120 \text { см) } & \end{array}$

$14,1 \pm 0,20$
$13,2 \pm 0,16$
$15,8 \pm 0,23$
$16,1 \pm 0,25$
$15,7 \pm 0,22$
0,5
9,5
3,5

$44 \pm 0,3$
$45 \pm 0,3$
$43 \pm 0,3$
$45 \pm 0,4$
$41 \pm 0,3$
2
2
4,5

$\begin{array}{cc}15,2 \pm 0,14 & 78 \pm 0,7 \\ 15,5 \pm 0,17 & 82 \pm 0,8 \\ 14,5 \pm 0,13 & 75 \pm 0,7 \\ 0,6 & 3 \\ 3,9 & 5 \\ 3,9 & 3,8\end{array}$

\section{$14,6 \pm 0,15 \quad 96 \pm 0,9$}

$15,2 \pm 0,13 \quad 100 \pm 0,9$

$14,3 \pm 0,10 \quad 92 \pm 0,8$

$15,6 \pm 0,15 \quad 103 \pm 0,9$

$15,8 \pm 0,16 \quad 87 \pm 0,8$

$15,0 \pm 0,14 \quad 89 \pm 0,8$

$14,1 \pm 0,15 \quad 98 \pm 0,8$

$14,7 \pm 0,15 \quad 98 \pm 0,9$

$\begin{array}{cc}0,6 & 4 \\ 18,9 & 7 \\ 3,8 & 4,2\end{array}$

$14,4 \pm 0,17 \quad 110 \pm 0,9$

$14,4 \pm 0,16 \quad 113 \pm 0,9$

$14,7 \pm 0,18 \quad 110 \pm 0,9$

$13,9 \pm 0,10 \quad 109 \pm 0,9$

$13,9 \pm 0,11 \quad 106 \pm 0,9$

$13,7 \pm 0,09 \quad 110 \pm 0,9$

$\begin{array}{cc}0,6 & 4 \\ 4,7 & 3 \\ 3,7 & 3,6\end{array}$

$\begin{array}{cc}13,2 \pm 0,10 & 125 \pm 1,1 \\ 14,7 \pm 0,15 & 122 \pm 1,1 \\ 14,1 \pm 0,13 & 120 \pm 1,1 \\ 15,3 \pm 0,18 & 129 \pm 1,5 \\ 13,7 \pm 0,09 & 127 \pm 1,2 \\ 0,5 & 5 \\ 11,6 & 2 \\ 3,9 & 4,0\end{array}$

П р и м е ч а н и е. $C v-$ коэффициент вариации, $\mathrm{Sx}-$ относительная ошибка опыта. Отцовской формой всех генотипов был образец пшеницы спельта из предгорных районов Карпат. Номера генотипов приведены согласно полевому журналу.

Спельтоидная форма колоса гексаплоидных видов пшениц контролируется геном $S$, доминантный аллель которого влияет на длину и плотность колоса. Кроме того, на длину колоса влияет ген $C$, доминатный аллель которого вызывает его укорачивание (34). При скрещивании спельты, несущей доминантные аллели гена $S$, с пшеницей мягкой, которая содержит ген $C$, в поколениях потомков наблюдается в основном промежуточное наследование длины и плотности колоса. Так, по длине колоса полученные нами образцы занимали промежуточное положение между исходными формами, а по его плотности были более близки к спельте (менее 16 шт. колосков на 10 см длины колосового стержня).

У низкорослых и высокорослых образцов отмечалась средняя степень варьирования по массе зерна с главного колоса $(C v=12,25-13,45 \%)$. Существенное увеличение этого показателя было отмечено у всех исследованных образцов, за исключением номеров 13 и 40. По числу зерен в коло- 
2. Качество зерна и продуктивность у лучших образцов пшеницы спельта (F5-11), созданных посредством гибридизации Triticum аеsti-

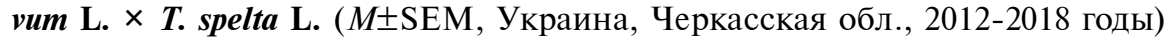

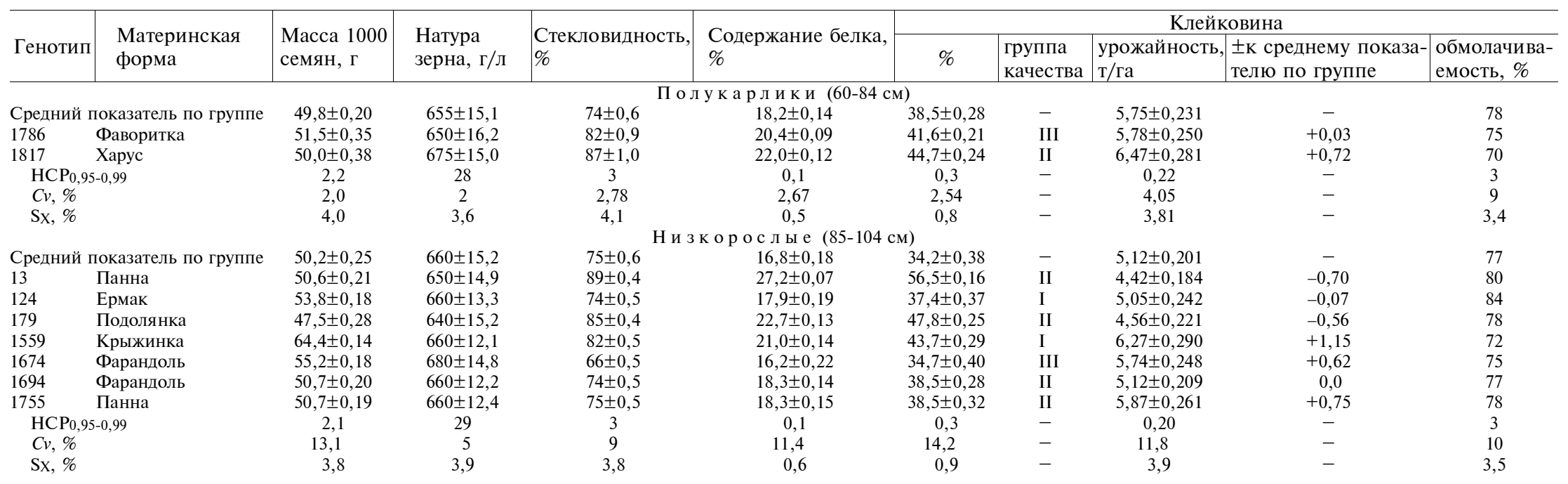




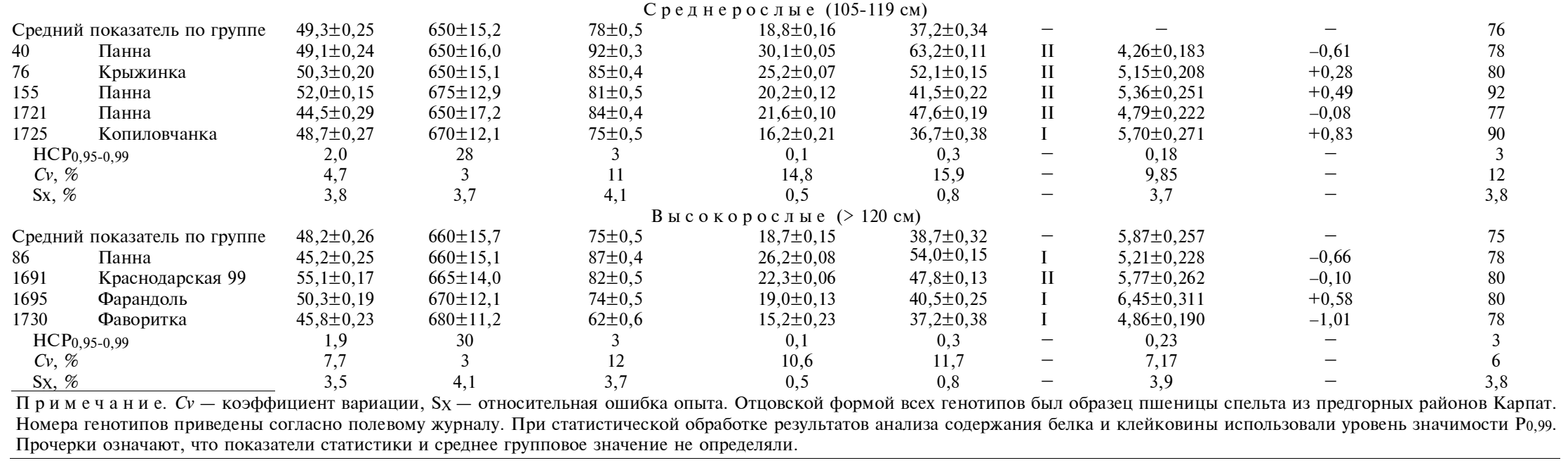


се образец 1559 (48 шт.) значительно превосходил групповой стандарт. Значение показателя у других форм, кроме 13 и 40, было сопоставимо со стандартами.

В процессе гибридизации пшеницы мягкой со спельтой важно сохранить высокое содержание белка и клейковины в зерне. При скрещивании родительской формы пшеницы с высоким содержанием белка и клейковины с формой, у которой значение этих показателей низкое, у потомков наблюдается наследование характеристик худшего из родителей (16, 19). Для создания новых форм спельты следует привлекать в систему гибридизации сильные и ценные по качеству зерна исходные формы. В наших исследованиях такой формой был сорт озимой мягкой пшеницы Панна. Потомки от скрещиваний этого сорта со спельтой имели наиболее высокие показатели содержания белка и клейковины в зерне, в частности среднерослый образец 40 и низкорослый 13 характеризировались содержанием белка соответственно 30,1 и 27,2 \%, клейковины - 63,2 и 56,5 \%, что существенно превышало средний групповой показатель (табл. 2).

Решающую роль для хлебопечения имеет не количество клейковины, а ее качество. Физические показатели качества, такие как цвет, растяжимость, эластичность и индекс деформации (ИДК), в значительной степени, влияют на процесс образования теста и выход хлеба. Согласно ГСТУ 3768:2010 (35), клейковина I группы качества должна быть светлосерого или серого цвета, эластичной, с растяжимостью в пределах 1020 см и иметь ИДК 45-85 ед. измерителя деформации клейковины ВДК-М (Украина). Группа качества может быть снижена, если индекс деформации выходит за рамки границ, допустимых для I группы, поскольку именно ИДК служит важнейшим показателем качества клейковины. В наших исследованиях клейковину I группы качества имели шесть образцов (см. табл. 2). Особенно следует отметить высокорослый образец 86, который также выделялся высоким содержанием клейковины $(54,0$ \%).

Стекловидность - важный показатель, определяющий пригодность зерна для переработки. Стекловидность зерна исследованных нами образцов спельты колебалась в пределах 62-92\%. Наиболее высокой она была у образцов 40 (92 \%), 13 (89 \%) и 1817 (87\%). Для пшеницы стекловидным считается зерно, у которого значение этого показателя превышает 70 \%, полустекловидным - 50-69 \%, полумучнистым - 21-49 \%, мучнистым $<20 \%$. Зерно всех образцов в опыте было стекловидным, за исключением 1674 и 1730, которые имели полустекловидную консистенцию эндосперма.

Масса 1000 зерен у исследуемых образцов колебалась в пределах 44,5-64,4 г. Значительное увеличение этого показателя относительно среднего группового стандарта зафиксировали у образцов 124 (53,8 г), 1559 $(64,4$ г), 1674 (55,2 г), 155 (52,0 г) и 1691 (55,1 г). По урожайности существенно превосходили стандарт образцы 76, 155, 1559, 1674, 1695, 1725 , 1755 и 1817. Стоит отметить высокорослый образец 1695, сочетающий продуктивность 6,52 т/га с высокими показателями качества зерна (масса 1000 зерен - 50,3 г, содержание белка - 19,0 \%, клейковины I группы качества $-40,5 \%$ ) и среднерослый образец 155, у которого все показатели качества и продуктивности существенно превышали групповой стандарт.

Спельта характеризуется трудной обмолачиваемостью зерна, что связано с ломкостью колосового стержня и наличием грубой колосковой пленки. Пшеница спельта отличается от пшеницы мягкой наличием рецессивного аллеля $q$ гена $Q$, который контролирует характер обмолота зерна (легкий или трудный). Наличие рецессивного аллеля $q$ в гомозиготном состоянии обусловливает формирование спельтоидного (длинного, 
ломкого, рыхлого) колоса с трудной обмолачиваемостью (36). Кроме того, на характер обмолота влияет тип колосковой чешуи, который у гексаплоидных видов пшениц контролируется рецессивным аллелем $\operatorname{tg}$ гена $\mathrm{Tg}$ в гомозиготном состоянии (36). Поскольку у спельты присутствуют доминантные аллели этого гена, у нее формируется колос с грубой колосковой пленкой, что отрицательно влияет на характер обмолота. У потомков от скрещивания пшеницы мягкой со спельтой были выявлены различные сочетания аллелей генов $Q$ и $T g$. В связи с этим у них фиксировали и разную обмолачиваемость, и неодинаковое строение колосковой пленки. Вероятно, образцы 76, 155, 1695 и 1725 имели генотип QQtgtg, что привело к формированию фенотипа с улучшенным обмолотом зерна (80-90\%).

Вегетационный период пшеницы спельта длится на 7-10 сут дольше по сравнению с пшеницей мягкой. Среди изученных нами образцов выделялись формы, сроки колошения и созревания которых были сопоставимы со сроками у раннеспелых сортов пшеницы мягкой. Образцы 1674 и 155 имели вегетационный период 280-285 сут, при этом их урожайность $(5,74-5,86$ т/га) существенно превышала стандарт.

В 2013 и 2015 годах посевы пшеницы спельта оказались поражены возбудителем бурой ржавчины Puccinia recondita Rob. ex Desm f. sp. tritici. У образцов 13 и 124 наблюдалась высокая резистентность к этому возбудителю. Интенсивность поражения у них составляла менее 5 \% листовой поверхности, что по шкале устойчивости соответствует 8-9 баллам. Очевидно, что они унаследовали признак устойчивости от родительских форм (сортов мягкой пшеницы Ермак и Панна, а также исходной формы спельты), которые проявляют высокую резистентность к возбудителю бурой ржавчины. Гены устойчивости к этому заболеванию у мягкой пшеницы находятся в гетерозиготном состоянии, в связи с чем не все потомки одних и тех же родительских форм оказались устойчивыми.

Полученные нами образцы постоянно апробируются. Среди них успешно ведется поиск новых доноров ценных признаков. В результате селекции создан сорт озимой пшеницы спельта Европа, который занесен в который занесен в Державний реєстр сортів рослин, придатних для поширення в Україні (с 2015 года). Выделены образцы 124 и 155, которые после размножения будут переданы на Государственную научнотехническую экспертизу.

Сорт Европа (селекционный образец 1725) - остистая форма пшеницы спельта, у которой 90 \% зерна отделяется от пленок во время обмолота. Сорт получен при гибридизации сорта озимой мягкой пшеницы Копиловчанка и спельты с использованием многоразового индивидуального отбора. Тип развития - озимый, высота растений - 110 см, содержание белка в зерне - $17 \%$, клейковины I группы качества - 38 \%, масса 1000 семян - 47 г, натура зерна - 670 г/л. За период Государственной научнотехнической экспертизы (2012-2015 годы) сорт имел среднюю урожайность в зоне лесостепи 5,82 т/га. Сорт устойчив к бурой ржавчине, мучнистой росе, снежной плесени и толерантен к желтой пятнистости, фузариозу колоса и корневым гнилям. Селекционный образец 124 был создан посредством гибридизации пшеницы мягкой озимой сорта Ермак со спельтой. Тип развития - озимый. Образец низкорослый (высота растений 92 см), среднеспелый (вегетационный период 290-295 сут). Колос безостый, длинный, неплотный. Образец характеризуется высокими показателями качества зерна, в частности массой 1000 зерен - 53,8 г, содержанием белка $17,9 \%$, клейковины I группы качества - 37,4 \%. Его продуктивность составляет 5,05 т/га. Селекционный образец 155 был получен в результате 
гибридизации пшеницы мягкой озимой сорта Панна со спельтой. Образец относится к озимым, среднерослым (109 см), среднеспелым (290-295 сут) формам, имеет безостый, длинный (16,5 см), неплотный колос. Сочетает высокие показатели качества зерна (масса 1000 зерен - 52,0 г, натура зерна - 675 г/л, содержание белка - 20,2 \%, клейковины - 41,5 \%) с продуктивностью 5,36 т/га и обмолачиваемостью $92 \%$.

Таким образом, с помощью отдаленной гибридизации пшеницы мягкой озимой и пшеницы спельта создана коллекция образцов пшеницы спельта, которая включает более 200 номеров. В состав коллекции входят уникальные рекомбинантные формы, различающиеся по хозяйственно ценным показателям, морфобиологическим и биохимическим свойствам. Выделены формы пшеницы спельта с хозяйственно ценными признаками: образец 124 - низкорослый (высота растений 92 см), с высокими показателями качества зерна (масса 1000 зерен - 53,8 г, содержание белка $17,9 \%$, клейковины I группы качества - 37,4 \%), образец 155 выделяется высокой продуктивностью (5,36 т/га) и улучшенной обмолачиваемостью зерна (92\%). При гибридизации пшеницы мягкой и спельты создан сорт озимой пшеницы спельты Европа, который занесен в Державний реєстр сортів рослин, придатних для поширення в Україні.

\section{ЛИТЕРАТУРА}

1. Packa D., Załuski D., Graban Ł., Lajszner W. An evaluation of spelt crosses for breeding new varieties of spring spelt. Agronomy, 2019, 9(4): 167 (doi: 10.3390/agronomy9040167).

2. Matsuoka Y. Evolution of polyploid Triticum wheats under cultivation: the role of domestication, natural hybridization and allopolyploid speciation in their diversification. Plant and Cell Physiology, 2011, 52(5): 750-764 (doi: 10.1093/pcp/pcr018).

3. Dvorak J., Deal K.R., Luo M.-C., You F.M., von Borstel K., Dehghani H. The origin of spelt and free-threshing hexaploid wheat. Journal of Heredity, 2012, 103(3): 426-441 (doi: 10.1093/jhered/esr152).

4. Нінієва А.К., Козуб Н.О., Созінов І.О., Рибалка О.І., Леонов О.Ю., Твердохліб О.В., Богуславський Р.Л. Характеристика зразків Triticum spelta L. за показниками якості зерна і електрофоретичному спектру запасних білків. Вісник українського товариства генетиків і селекціонерів, 2013, 11(1): 96-105.

5. Lacko-Bartošová M., Korczyk-Szabó J., Ražný R. Triticum spelta - a specialty grain for ecological farming systems. Research Journal of Agricultural Science, 2010, 42(1): 143-147.

6. Ruibal-Mendieta N.L., Delacroix D.L., Mignolet E., Pycke J.M., Marques C., Rozenberg R., Petitjean G., Habib-Jiwan J.-L., Meurens M., Quetin-Leclercq J., Delzenne N.M., Larondelle Y. Spelt (Triticum aestivum spp. spelta) as a source of bread making flours and bran naturally enriched in oleic acid and minerals but not phytic acid. Journal of Agricultural and Food Chemistry, 2005, 53(7): 2751-2759 (doi: 10.1021/jf048506e).

7. Diordiieva I., Riabovol L., Riabovol I., Serzhuk O., Novak A., Kotsiuba S. The characteristic of wheat collection created by Triticum aestivum L./Triticum spelta L. hybridization. Agronomy Research, 2018, 16(5): 2005-2015 (doi: 10.15159/AR.18.181).

8. Geisslitz S., Longin C.F.H., Scherf K.A., Koehler P. Comparative study on gluten protein composition of ancient (einkorn, emmer and spelt) and modern wheat species (durum and common wheat). Foods, 2019, 8(9): 409 (doi: 10.3390/foods8090409).

9. Sobczyk A., Pycia K., Stankowski S., Jaworska G., Kuzniar S. Evaluation of the rheological properties of dough and quality of bread made with the flour obtained from old cultivars and modern breeding lines of spelt (Triticum aestivum ssp. spelta). Journal of Cereal Science, 2017, 77: 35-41 (doi: 10.1016/j.jcs.2017.07.013).

10. Arzani A., Ashraf M. Cultivated ancient wheats (Triticum spp.): a potential source of health-beneficial food products. Comprehensive Reviews in Food Science and Food Safety, 2017, 16(3): 477-488 (doi: 10.1111/1541-4337.12262).

11. Господаренко Г.М, Любич В.В., Полянецька І.О. Амінокислотний склад білка пшениці спельти залежно від походження сорту та лінії. Вісник Уманського національного університету садівництва, 2016, 2: 44-48.

12. Господаренко Г.М., Костогриз П.В., Любич В.В., Парій М.Ф., Полторецький С.П., Полянецька I.О., Рябовол Я.С., Рябовол Л.О., Сухомуд О.Г. Пшениця спельта. Монографія. Київ, 2016.

13. Митрофанова О.П. Генетические ресурсы пшеницы в России: состояние и предселекци- 
онное изучение. Вавиловский журнал генетики и селекции, 2012, 16(1): 10-20.

14. Січкар С.М., Моргун В.В., Дубровна О.В. Характер успадкування морфологічних ознак колоса у гібридів Triticum spelta $\times$ Triticum aestivum. Фактори експериментальної еволюцї̈ організмів, 2016, 18: 149-153.

15. Liu G., Xu S.B., Ni Z.F., Xie C.J., Qin D.D., Li J., Lu L.H., Zhang J.P., Peng H.R., Sun Q.X. Molecular dissection of plant height QTLs using recombinant inbred lines from hybrids between common wheat (Triticum aestivum L.) and spelt wheat (Triticum spelta L.). Chinese Science Bulletin, 2011, 56(18): 1897-1903 (doi: 10.1007/s11434-011-4506-z).

16. Nemeth C., Yang C., Kasprzak P., Hubbart S., Scholefield D., Mehra S., Skipper E., King I., King J. Generation of amphidiploids from hybrids of wheat and related species from the genera Aegilops, Secale, Thinopyrum, and Triticum as a source of genetic variation for wheat improvement. Genome, 2015, 58(2): 71-79 (doi: 10.1139/gen-2015-0002).

17. Babenko L.M., Hospodarenko H.M., Rozhkov R.V., Pariy Y.F., Pariy M.F., Babenko A.V., Kosakivska I.V. Triticum spelta: Origin, biological characteristics and perspectives for use in breeding and agriculture. Regulatory Mechanisms in Biosystems, 2018, 9(2): 250-257 (doi: 10.15421/021837).

18. Osokina N., Liubych V., Novak L., Pushkarova-Bezdil T., Priss O., Verkholantseva V., Hryhorenko O., Pusik V., Pusik L. Elucidation of the mechanism that forms bread baking properties of the spelt grain. Eastern European Journal of Enterprise Technologies, 2018, 2/11(92): 39-47 (doi: 10.15587/1729-4061.2018.126372).

19. Рибалка О.І. Якість пшениці та ї поліпшення. Монографія. Київ, 2011.

20. Парій Ф.М., Сухомуд О.Г., Любич В.В. Оцінка господарсько цінних властивостей нового сорту пшениці спельти озимої Зоря України. Насінництво, 2013, 5: 5-6.

21. Діордієва І.П. Лінії пшениці спельта Уманского НУС. Генетичні ресурси рослин, 2018, 23: $25-34$.

22. Твердохліб О.В., Голик О.В., Нінієва А.К., Богуславский Р.Л. Спельта і полба в органічному землеробстві. Посібник Українського хлібороба, 2013, 2: 154-155.

23. Державний реєстр сортів рослин, придатних для поширення в Україні в 2019 р. Київ, 2019.

24. Методика Державної науково-технічної експертизи сортів рослин. Методи визначення показників якості продукції рослинництва. Київ, 2015.

25. Дорофеев В.Ф., Удачин Р.А., Семенова Л.В. Пиеницы мира. Ленинград, 1987.

26. Эрмантраут Э.Р., Гудзъ В.П. Статистический анализ результатов агрономических исследований в прикладной программе «EXCEL-2000». Мam. Межд. науч.-практ. конф. «Современные проблемы опытного дела». СПб, 2000, 2: 13-134.

27. Кочмарський В.С. Оцінка зразків пшениці м'якої озимої світового генофонду за висотою рослин і остистістю колоса. Таврійський науковий вісник, 2012, 78: 33-38.

28. Longin C.F.H., Ziegler J., Schweiggert R., Koehler P., Carle R., Würschum T. Comparative study of hulled (einkorn, emmer, and spelt) and naked wheats (durum and bread wheat): agronomic performance and quality traits. Crop Science, 2016, 56(1): 302-311 (doi: 10.2135/cropsci2015.04.0242).

29. Rapp M., Beck H., Gütler H., Heilig W., Starck N., Römer P., Cuendet C., Kurz H., Uhlig F., Würschum T., Friedrich C., Longin F. Spelt: agronomy, quality, and flavor of its breads from 30 varieties tested across multiple environments. Crop Science, 2017, 57(2): 739747 (doi: 10.2135/cropsci2016.05.0331).

30. Твердохлеб Е.В., Богуславский Р.Л. Формообразовательный процесс у гибридов Triticum kiharae Dorof. et e. Migusch. c T. aеstivum L. Вісник Харківського національного аграрного університету, 2010, 2(20): 88-95.

31. Ivanovska S., Kraljević-Balalić M., Stojkovski C. Diallel analysis for plant height in winter wheat. Genetika, 2003, 35(1): 11-19 (doi: 10.2298/GENSR0301011I).

32. Січкар С.М., Моргун В.В., Дубровна О.В. Успадкування морфологічних ознак у гібридів F1-F2 T. spelta $\times$ T. aestivum. Физиология растений и генетика, 2016, 48(4): 344-355.

33. Гулканян В.О. О наследовании признака высоты растений пшеницы при гибридизации. Биологический журнал Армении АН Армении, 1971, 23(4): 41-49.

34. Grant N.P., Mohan A., Sandhu D., Gill S.K. Inheritance and genetic mapping of the reduced height (Rht18) gene in wheat. Plants, 2018, 7(3): 58-67 (doi: 10.3390/plants7030058).

35. Пшеница. Технические условия: ГСТУ 3768:2010. Киев, 2010.

36. Faris J.D., Simons K.J., Zhang Z., Gill B.S. The wheat super domestication gene Q. Frontiers of Wheat Bioscience, 2005, 100: 129-148.

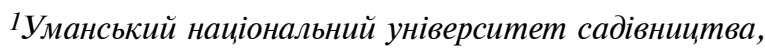

Кафедра генетики, селекції рослин та біотехнології,

20305 Україна, Черкаська обл., м. Умань, вул. Їнститутська, 1,

e-mail: diordieva201443@gmail.com ( $₫$ corresponding author),

Genetika2015@udau.edu.ua, Liudmila1511@ukr.net;

2Державне підприємство Дослідне господарство «Еліта»

Миронівського інституту пшениці ім. В.М. Ремесла

НААН України,
Поступила в редакцию 5 февраля 2020 года 


\title{
BREEDING OF SPELT WHEAT (Triticum spelta L.) ON PRODUCTIVITY AND GRAIN QUALITY
}

\author{
I.P. Diordiieval, Ia.S. Riabovol', V.S. Kochmarskyi², L.O. Riabovol ${ }^{1}$
}

${ }^{1}$ Uman National University of Horticulture, Department of Genetics, Plant Breeding and Biotechnology, 1, Institutska vul., Uman, Cherkassy region, 20305 Ukraine, e-mail diordieva201443@gmail.com ( $\triangle$ corresponding author), Genetika2015@udau.edu.ua, Liudmila1511@ukr.net;

${ }^{2}$ Experimental Farm «Elite» of Remeslo Mironovskyi Institute of Wheat NAASU, v. Central, Mironovskyi region, 08853 Ukraine, e-mail elitamip@ukr.net

ORCID:

Diordiieva I.P. orcid.org/0000-0002-8534-5838

Riabovol Ia.S. orcid.org/0000-0003-4325-5313

The authors declare no conflict of interests

Received February 5, 2020
Riabovol L.O. orcid.org/0000-0001-8988-4874

Kochmarskyi V.S. orcid.org/0000-0002-1990-1808

doi: 10.15389/agrobiology.2020.3.552eng

\section{Abstract}

Spelt (Triticum spelta L.) is an ancient specie of wheat demand for which is currently increasing. Along with positive characteristics of spelt (high protein, gluten and amino acids content, high adaptive potential, presence of a powerful stem and high resistance to lodging) it is significantly inferior to soft wheat T. aestivum L. in terms of yield capacity. However, new perspective genotypes with improved quantitative traits can be obtained from crosses of spelt and soft wheat due to introgression of genetic material of $T$. aestivum into $T$. spelta genome. In present research in result of hybridization of spelt wheat and soft wheat we obtained new forms which differ from each other in terms of morphobiological and economically valuable traits. The research aimed to create new initial material of spelt with high quality of grain based on hybridization of Triticum aestivum and T. spelta and its introduction to the breeding scheme for creating high productive varieties of the crop. Samples of spelt wheat obtained by the method of remote hybridization followed by multiple individual selection. Spelt samples of local breeding from foothill regions of the Carpathians and regionalized varieties of winter wheat Favoritka, Kharus, Panna, Ermak, Podolianka, Kryzhynka, Farandol, Kopilovchanka, Krasnodarskaia 99 were used as initial breeding material. Derived F1 hybrids were self-pollinated or back-crosses with parental forms. Hybrid progenies F2-5 were analyzed in terms of morphobiological and economically valuable traits (plant height, shape of the bush, wax coating on plants, pubescence on the stem and spike, length, color and awnedness of the spike, number of spikelets in the spike, density of the spike, threshing of grain, grain shape and color, weight of the grain from the main spike, number of productive stems per plant, 1000-grain weight, gluten and protein content, grain hardness, productivity). In fifth generation (F5) when segregation was no longer observed, considering productivity and quality of previous years, 18 best samples of spelt wheat were selected. Their field testing was conducted during 2012-2018 (F5-11) (a research field of Uman National University of Horticulture, right-bank Forrest-steppe of Ukraine, Cherkassy region). Gluten and protein contents were determined by infrared spectroscopy (Laboratory of genetics, breeding and seed production, a device Infratec ${ }^{\mathrm{TM}}$ Nova, FOSS Analytical, Sweden). Biometric traits (plant height, ear length, number of grains per ear, grain weight from head ear) were determined on 50 plants selected from each plot in two non-adjoin repetitions. Grain threshing was performed, and yield capacity was determined. From crossing, the collection of spelt initial material which include more than 200 samples was created. Obtained forms were divided into four groups according to plant height: semidwarf, low-growing, medium-growing and high-growing. In each group the best samples were selected which were analyzed for grain quality, yield and productivity structure. A possibility was proved of breeding improvement of spelt based on interspecific hybridization with soft wheat. It was established that eight samples significantly exceeded standard for yields. In the same time samples Nos. 76, 155, 1695 и 1725 had improved grain threshing (80-90\%), samples Nos. 76 and 1817 were characterized by high quality, in particular, 25.2 and $22.0 \%$ protein content, respectively, and 52.1 and $44.7 \%$ gluten level. Samples Nos. 40 and 13 were the best in terms of gluten and protein content with 30.1 and $27.2 \%$ for protein, and 63.2 and $56.5 \%$ for gluten, respectively. As a result of the study, spelt wheat forms were selected which possess several valuable traits, i.e. the sample No. 124 is distinguished due to low plant height $(92 \mathrm{~cm})$ and high quality traits $(1000$-grain weigh of $53.8 \mathrm{~g}$, protein content of $17.9 \%$, I group gluten level of $37.4 \%$ ), while the sample No. 155 shows high productivity $(5.36 \mathrm{t} / \mathrm{ha})$ and an improved grain threshing out from the ear $(92 \%)$. A winter spelt variety Europe derived from spelt and soft wheat hybridization has been listed to State register of plants suitable for growing in Ukraine from 2015.

Keywords: spelt wheat, soft wheat, hybridization, yield capacity, grain threshing, protein content, gluten content. 